\title{
Sex Ratio Analysis of Some Macrolepidoptera Species Collected by Hungarian Forestry Light Traps
}

\author{
László NOwINSZKY* - János PUSKÁS \\ Savaria University Centre, University of West Hungary, Szombathely, Hungary
}

\begin{abstract}
We analysed the sex ratio of 32 macrolepidopteran species caught by Hungarian forestry light traps. That the ratio of males and females collected by light trap varies by species has been known for decades; however, the sex ratio found in the natural population is not known. All 32 species were processed separately, but by the same method. Both males and females were counted throughout the whole swarming. We calculated these figures and inspected the difference in the level of significance with the $\chi^{2}$ test. For each swarming we calculated the percentage of males and females. We also calculated the values of the variation coefficients, which express the deviations in average percentages.

Males make up the majority of the moths captured in the trap; this result was mirrored by 29 of the 32 species investigated. One of the exceptions was the Pelosia muscerda $\mathrm{Hfn}$. where we observed a male to female ratio that was equal. In addition to that Watsoniana cultraria Fabr. is the only one species captured by light traps that showed a significant female majority.

Our results confirm that the majority of moths captured in traps are males. However, the proportion of males and females of each species, and even within the same species, tended to differ greatly with each swarming. Yet, it must be noted that these results speak only for those specimens captured by light traps and cannot be related directly to the actual sex ratio of populations living in the natural environment.
\end{abstract}

\section{Macrolepidoptera / sex ratio / forestry light-trap / Hungary}

Kivonat - A magyar erdészeti fénycsapdák által gy jtött néhány macrolepidoptera faj ivararányának elemzése. Évtizedek óta ismert, hogy fénycsapdával gy jtött hímek és n stények aránya fajonként változik. Nem ismert azonban, hogy milyen a nemek aránya a természetes populációban. 32 fénycsapdával gy jtött Macrolepidoptera faj hím és n stény arányát elemeztük. Minden fajt különkülön dolgoztunk fel, de azonos módszerrel. Mind a hímeket, mind n stényeket megszámoltuk egész rajzás során. Ezeket összeadtuk és az eltérések szignifikancia szintjét $\chi^{2}$ próbával ellen riztük. Kiszámítottuk a variációs koefficiens értékeket is, amelyek az eltéréseket az átlag százalékában fejezi ki.

Megállapítottuk, hogy a vizsgált 32 fajból 29 rajzásban magasabb volt a befogott hímek száma, mint a n stényeké. Kivétel volt a hamvas zuzmószöv (Pelosia muscerda Hfn.), amelynél a hím és n stény arány egyenl és egyetlen faj bükkfa sarlósszöv (Watsoniana cultraria Fabr.), amelynél a n stények voltak többségben.

Eredményeink szerint a legtöbb faj esetében több a fénycsapdával befogott hím mint n stény, azonban ez az arány az egyes fajoknál, de még ugyanazon faj, más és más rajzásában is nagyon különböz . Ezek az eredmények azonban nem vonatkoznak közvetlenül a természetben él populációk valós hím-n stény arányaira, hanem csak a fénycsapdás fogásokra.

\section{Macrolepidoptera / hím n stény arány / erdészeti fénycsapda / Magyarország}

\footnotetext{
* Corresponding author: lnowinszky@ gmail.com; H-9700 SZOMBATHELY, Károlyi G. tér 4.
} 


\section{INTRODUCTION}

That the proportion of males and females captured by light trap varies by species has been known for decades; however the sex ratio within the natural population is unknown.

Within the various orders of insects, Williams (1939) studied the sex ratio by species of the specimens caught. Of the 51 species of the Noctuidae family, the females of 2 species were not attracted to light at all. The females of 27 species represented 1-20\% of the total number of specimens: this ratio was $20-46 \%$ with 16 species: the number of males and females was identical in the case of 3 species and there were only 3 species where more females than males were attracted to light. There is also a behavioural dimorphism: in 2 samples of 37 individuals of ghost moth (Hepialus humuli L.) only $22 \%$ males flew to light traps even though sweep net samples gave an approximately 50:50 sex-ratio (Williams 1939). According to Mallet (1984), in the case of Hepialus humuli L. more females than males are attracted to light, which suggests that the females are the more mobile gender.

Nanu König (1968) examined 13 Lepidoptera families to establish the ratio of males and females attracted by light. The females of the various families represented $0.2-30 \%$ of the catch. Schurr (1971) captured mostly male specimens of the vine moth (Eupoecilia ambiguella $\mathrm{Hbn}$.) with his trap running on white light (of 510-610 nm). Járfás et al. (1974) used different sources of light to study the sex ratio of the turnip moth (Agrotis segetum Den. et Schiff.). Whatever the light source, the proportion of males was between 48-66\%. Czencz (1973) holds that the males of the diamondback moth (Plutella xylostella L.) are more drawn to light than the females (75-25\%). She does not provide any explanation for this, however.

Bürgés Gál (1980), with a 125W mercury light trap, found that with the nut fruit tortrix (Cydia splendana $\mathrm{Hbn}$.), males appear 3-4 days earlier than females. The male to female ratio is 1.9:1. This was almost the same as the male to female ratio of the European chestnut weevil (Curculio elephas Gyllenhal), which was 1.83:1.

Egyptian Bollworm (Earias insulana Boisduval) moths were collected by Yathom (1981) from mercury vapour light traps operating in Israel between 1974 and 1980. He concludes that the sex ratio generally favoured males.

El-Abdullah et al. (1984) report on a mere 10\% of the trapped specimens of the Asiatic rice borer (Cilo suppressalis Walker) being males. Skuhravý et al. (1993) caught male specimens of the saddle gall midge (Haplodiplosis marginata von Roser) almost exclusively, both with a Minnesota-type and a UV light trap.

Itämies et al. (1986) employed a light trap to examine the flight pattern of grey mountain carpet (Entephria caesiata Den. et Schiff.) between 1978 and 1982 in the Finnish forest areas of Lapland. With the exception of 1978, males dominated the catch, although this dominance was not overwhelmingly high.

Some researchers have published statements of general validity. Novák (1974) has published sex index data relating to 96 species of moths trapped. Depending on the ratio of females, he arranged the species examined into five classes and, within certain limits, he regarded his results as constant. Malicky (1974) also believes that the sex ratio of a captured species is the same over many years through the use of the same source of light at different places of observation; in other words, sex ratio is value specific to a given species. Szarukán (1975) claims that the average proportion of female specimens of the dog's tooth (Lacanobia suasa Schiff.) is $33 \%$. He found minimal difference between the first and second generations. A study in Egypt (Sadek 2001), found that $8.04 \%$ of the female mediterranean brocade (Spodoptera littoralis Fabr.) specimens that had been trapped had not been fertilized, while the ratios of those fertilized once or more than once were $37.25 \%$ and $54.76 \%$. The sex ratio of the sulphur knapweed moth (Agapeta zoegana L.) was equal when examined at daytime, but at night the overwhelming majority of the specimens caught by light trap were male. The 
difference may be explained by the dissimilar reaction of the two sexes to light (Story et al. 2001). In Switzerland Cordillot Duelli (1986) noticed that the ratio of females captured by light trap in one generation of European corn-borer (Ostrinia nubilalis $\mathrm{Hb}$.) was $47.3 \%$. The above mentioned authors regard sex ratio as a static value specific to a species, despite the fact that the annual differences in sex ratio are valuable results related to population changes and not statistical deviation data without a biological value (Sze ke Szarukán 1982). According to Mohai Herczig (1979) and also to Lesznyák et al. (1993), the proportion in percentage of females rises and falls in harmony with the rise and fall of the amount of insects caught in light traps. The latter of the abovementioned authors have found that the ratio of females is affected first of all by the minimum values of temperature. El-Deeb (1992) established that the number of European corn-borer (Ostrinia nubilalis Hbn.) females captured by light trap surpassed that of the males. However, the ratio was affected positively by maximum and minimum temperature, and negatively by relative vapour content.

Some authors have found that both males and females have to be in a certain physiological state to be attracted to sources of light. Terskov Kolomiec (1966) report that females of the white satin moth (Leucoma salicis L.) can be trapped before egg laying, while those of the gypsy moth (Lymantria dispar L.) in Siberia are more prone to be trapped after egg-laying. This latter bit of information is of special interest because there are no data in literature about how gypsy moth females of the European and American populations fly to light considering that the females there are incapable of flight. In contrast to that females of the gypsy moth (Lymantria dispar L.) population in East Asia do fly (Wallner et al. 1995; Reineke Zebitz 1998; Charlton et al. 1999). Females of the European corn-borer (Ostrinia nubilalis $\mathrm{Hbn}$.), on the other hand, may fly to light any time following their emergence from the pupal state (Showers et al. 1974). Then again, Elliott Dirks (1979) claim they are trappable in the largest numbers $3.2-4.4$ days after mating.

Sathiyanandam Baskaran (1999) observed that the ratio of females of the groundnut leaf miner (Aproaerema modicella Deventer) in India changed during different periods in the night. The ratio of mated to unmated females also changed. The number of males and females of some caddis fly (Trichoptera) species caught by light traps in New Zealand displayed a definite change in swarming. Males were the majority at the start of the swarming, while females made up the majority at the end (Ward et al. 1996). Dickler Steuerwald (1997) found significant differences from one year to the next in the number of specimens as well as in the sex ratio of noctuids (Noctuidae) captured by light traps in apple orchards in Germany.

In the study of Myers et al. (1998) the sex ratio of gypsy moth (Lymanrtia dispar L.) pupae varied strikingly between low-density and high-density populations.

Altermatt et al. (2009) experimentally studied the flight to light behaviour of two moth species - the small ermine moth, Yponomeuta cagnagella (Hbn.), and the scorched carpet moth, Ligdia adustata (Den. et Schiff.). They found that male moths were significantly more (about 1.6 times more frequently) attracted to light than female moths. It was established that there is a sexual dimorphism in the flight to light behaviour of moths.

Garris Snyder (2010) investigated and recorded the sex ratio of 28 southern species in the USA. They tested the well-known view that UV light-trap collections of moths are considerably skewed toward males. Twelve species demonstrated a statistically notable male preponderance, but a wide range of sex ratios was found. Two of the 28 species demonstrated significant bias for both males and females during different observation periods, illustrating the need to collect over the entire flight period. Since the sex ratio of collected organisms varies by species and by time, this knowledge must be taken into consideration when using light trap collection to make population estimates and to gather information for conservation or control of any particular species. 
According to Tabadkani et al. (2013) appreciation of the proportion of genders of arthropods is a pertinent issue not only in ecological studies and in biological programs, but also in plant protection. In this study, they continued to examine the factors leading to erroneous estimates of sex ratios of insect species. They examined the predatory gall midge, Aphidoletes aphidimyza Rondani (Diptera: Cecidomyiidae), and the results explicitly suggest that direct estimation of the sex ratio in natural populations may be affected by some secondary factors such as differential mortality of sexes, protandry, and differential distribution of males and females over time and/or across habitat.

While they could provide us with important, useful information for everyday practice, there are very few publications reporting on research of this kind. Unfortunately, this kind of research is both time consuming and energy consuming; thus, in the foreseeable future, we cannot expect any major breakthrough in this area.

Researchers have been studying the sex ratio of the insects trapped for decades, but their observations had little practical value for plant protection prognostics. The authors of most studies confine themselves to releasing the figures recording the number of males and females, perhaps even their ratio in terms of percentage of the captured specimens, but they refrain from drawing any conclusions. Admittedly, any such attempt would be a vain endeavour, especially in the case of the data provided by light traps operating for short periods. Whereas if the sex ratio of the populations in the environment shifts in the direction of a preponderance of females and that change is reflected in the catch, a growth in the number of the females trapped might indicate the start of gradation. Therefore, awareness of the regularity of sex ratio transformation may also be used for the purposes of prognosis in the case of species where both sexes fly well to light. Some researchers have published general statements concerning this.

When the sex ratio of an observed species at different observation sites and in different years produces decidedly different values, it would be useful to examine regularities in changes. From the point of view of prognosis, the differences in time have main importance, because they might be related to hypercyclic movement. Our own research revealed a rise of the number of turnip moth (Agrotis segetum Den. et Schiff.) females in the years which were followed by gradation (in years 1962 and 1968) (Nowinszky Kiss 1981). It is assumed that the proportion of females affects the number of individuals of future generations. In the year prior to the years of gradation, the number of females increased.

We examined the changes of the number of the females in the turnip moth (Agrotis segetum Den. et Schiff.) population between 1957 and 1990. The light-trap catches of 65 observing stations were used (Kiss et al., 2003).

It is concluded that over 99 specimens in each generation the ratio of females is 0.38 from all individual number. If the number of individuals is between 5 and 99 , the proportion is 0.44 . The proportion of females is 0.46 if the number is between 100 and 499 ; it is 0.38 between 500 and 999 . Between 100 and 999 this value is 0.40 . For all observing stations, we calculated the female individual proportions and the $95 \%$ confidence intervals for them. We established that higher female proportion belongs to the lower individual numbers, but this proportion is close to the feature if individual numbers are high. It was observed that in the year before gradations begin, the rate of females was extremely high in many cases.

\section{MATERIAL}

The development of a light trap network began in 1952 in Hungary. The traps were used in research institutes, for plant protection, and for forestry purposes. The three-type light trap network is still working and works with uniformly Jermy-type traps. Over the past decades, 
the national light-trap network has provided an enormous and inestimable amount of scientific insect material for entomological research and plant protection practice (Nowinszky 2003).

The Jermy-type light trap (Jermy 1961) consists of a frame, a truss, a cover, a light source, a funnel, and a killing device. All the components are painted black, except for the funnel, which is white. A metal ring holding the funnel and a zinc-plated tin joins the steel frame. The cover is $100 \mathrm{~cm}$ in diameter. The distance between the lower edge of the cover and the higher edge of the funnel is $20-30 \mathrm{~cm}$. The light source is a $100 \mathrm{~W}$ normal electric bulb with a colour temperature of $2900^{\circ} \mathrm{K}$. The lamp is in the middle of the trussing, $200 \mathrm{~cm}$ above ground. The upper diameter of the funnel is $32 \mathrm{~cm}$, while the lower one is $5 \mathrm{~cm}$, and its height is $25 \mathrm{~cm}$. In each case chloroform was used as a killing agent.

The forestry light traps are operational from 6 p.m. (UT) to 4 a.m. every night of the year, regardless of weather, or the time of sunrise and sunset. The operation is suspended only on days when the temperature is below $0 \mathrm{C}^{\mathrm{O}}$ and the ground is covered by an unbroken layer of snow. All the insects trapped during the course of a night go into the same collecting jar and so a single set of data will represent the nightly catch result at the given observation site.

In this study we used the catch data of the Hungarian Forestry light trap network of the Forest Research Institute. The light traps were operating in 16 light trap stations across the whole territory of Hungary. The light trap stations, geographic coordinates and years of operation are presented in Table 1.

Table 1. The light trap stations, geographic coordinates and years of operation

\begin{tabular}{lcc}
\hline Light-trap stations & Geographic coordinates & Years of operation \\
\hline Budakeszi & $47^{\circ} 3083$ N $18^{\circ} 5603 \mathrm{E}$ & $1962-1970$ \\
Erd smecske & $46^{\circ} 1051$ N $18^{\circ} 3080 \mathrm{E}$ & 1970 \\
Fels tárkány & $47^{\circ} 5844$ N $20^{\circ} 2507 \mathrm{E}$ & $1961-1970$ \\
Gerla & $46^{\circ} 4201$ N $21^{\circ} 1107 \mathrm{E}$ & $1962-1970$ \\
Gyulaj & $46^{\circ} 3051$ N $18^{\circ} 1776 \mathrm{E}$ & 1970 \\
Makkoshotyka & $48^{\circ} 2152$ N $21^{\circ} 3117 \mathrm{E}$ & $1961-1970$ \\
Mátraháza & $47^{\circ} 4687$ N $19^{\circ} 5569 \mathrm{E}$ & $1961-1970$ \\
Répáshuta & $48^{\circ} 0290$ N $20^{\circ} 3170 \mathrm{E}$ & $1962-1970$ \\
Sopron & $47^{\circ} 4101$ N $16^{\circ} 3479 \mathrm{E}$ & $1962-1970$ \\
Szakonyfalu & $46^{\circ} 5545$ N $16^{\circ} 1371 \mathrm{E}$ & $1967-1970$ \\
Szentpéterfölde & $46^{\circ} 3702$ N $16^{\circ} 4564 \mathrm{E}$ & $1968-1970$ \\
Szombathely & $47^{\circ} 1401$ N $16^{\circ} 3722 \mathrm{E}$ & $1962-1970$ \\
Tolna & $46^{\circ} 2560$ N $18^{\circ} 4695 \mathrm{E}$ & $1962-1970$ \\
Tompa & $46^{\circ} 1228$ N $19^{\circ} 3808 \mathrm{E}$ & $1962-1970$ \\
Várgesztes & $47^{\circ} 2852$ N $18^{\circ} 2391 \mathrm{E}$ & $1962-1970$ \\
Zalaerd d & $47^{\circ} 0344$ N $17^{\circ} 0330 \mathrm{E}$ & 1970 \\
\hline
\end{tabular}

For our study, 32 forest phytophagous Macrolepidoptera species were selected from the national forestry light trap network material dating back to the years between 1961 and 1970 .

The species were selected based on data available from several light traps over many years. 
Table 2. Catching data of caught species

\begin{tabular}{|c|c|c|c|c|c|}
\hline \multirow[b]{2}{*}{ Families and species } & \multicolumn{5}{|c|}{ Number of } \\
\hline & $\begin{array}{l}\text { Light- } \\
\text { traps }\end{array}$ & Years & $\Sigma \sigma^{x}$ & $\Sigma$ ㅇ & $\begin{array}{l}x^{2} \\
\mathrm{P}<\end{array}$ \\
\hline \multicolumn{6}{|l|}{ Lasiocampidae } \\
\hline $\begin{array}{l}\text { December Moth } \\
\text { Poecilocampa populi (Linnaeus, 1758) }\end{array}$ & 2 & 9 & 2,817 & 317 & 0.01 \\
\hline $\begin{array}{l}\text { Autumn Eggar } \\
\text { Eurigaster rimicola (Denis et Schiffermüler, 1775) }\end{array}$ & 1 & 9 & 2,027 & 40 & 0.01 \\
\hline $\begin{array}{l}\text { Barred Hook-tip } \\
\text { Watsonalla cultraria (Fabricius, 1775) }\end{array}$ & 3 & 5 & 818 & 1,484 & 0.01 \\
\hline $\begin{array}{l}\text { Scarce Hook-tip } \\
\text { Sabra harpagula (Esper, 1786) }\end{array}$ & 2 & 5 & 888 & 134 & 0.01 \\
\hline \multicolumn{6}{|l|}{ Thyatiridae } \\
\hline $\begin{array}{l}\text { Popular Lutestring } \\
\text { Tethea or (Denis et Schiffermüller, 1775) }\end{array}$ & 3 & 8 & 2,353 & 929 & 0.01 \\
\hline \multicolumn{6}{|l|}{ Geometridae } \\
\hline $\begin{array}{l}\text { Maiden's Blush } \\
\text { Cyclophora punctaria (Linnaeus, 1758) }\end{array}$ & 1 & 4 & 1,197 & 1,331 & 0.01 \\
\hline $\begin{array}{l}\text { Clay Triple-lines } \\
\text { Cyclophora linearia (Hübner, 1799) }\end{array}$ & 4 & 7 & 4,005 & 4,864 & 0.01 \\
\hline $\begin{array}{l}\text { November Moth } \\
\text { Epirrita dilutata (Denis et Schiffermüller, 1775) }\end{array}$ & 3 & 2 & 1,216 & 114 & 0.01 \\
\hline $\begin{array}{l}\text { Dingy Shell } \\
\text { Euchoeca nebulata (Scopoli, 1763) }\end{array}$ & 8 & 8 & 2,656 & 427 & 0.01 \\
\hline $\begin{array}{l}\text { Sharp-angled Peacock } \\
\text { Macaria alternata (Denis et Schiffermüller, 1775) }\end{array}$ & 5 & 9 & 3,018 & 1,990 & 0.01 \\
\hline $\begin{array}{l}\text { Featheres Thorn } \\
\text { Colotois pennaria (Linnaeus, 1761) }\end{array}$ & 9 & 7 & 4,561 & 567 & 0.01 \\
\hline $\begin{array}{l}\text { Peppered Moth } \\
\text { Biston betularia (Linnaeus, 1758) }\end{array}$ & 5 & 8 & 4,359 & 34 & 0.01 \\
\hline $\begin{array}{l}\text { Pale Oak Beauty } \\
\text { Hypomecis punctinalis (Scopoli, 1763) }\end{array}$ & 9 & 9 & 12,715 & 2,938 & 0.01 \\
\hline $\begin{array}{l}\text { The Engrailed } \\
\text { Ectropis bistortata (Goeze, 1781) }\end{array}$ & 12 & 9 & 17,815 & 1,517 & 0.01 \\
\hline \multicolumn{6}{|l|}{ Notodontidae } \\
\hline $\begin{array}{l}\text { Buff-tip } \\
\text { Phalera bucephala (Linnaeus, 1758) }\end{array}$ & 3 & 4 & 495 & 7 & 0.01 \\
\hline $\begin{array}{l}\text { Plumed Prominent } \\
\text { Ptilophora plumigera (Denis et Schiffermüller, 1775) }\end{array}$ & 1 & 4 & 2,118 & 275 & 0.01 \\
\hline $\begin{array}{l}\text { Small Chocolate-tip } \\
\text { Clostera pigra (Hufnagel, 1766) }\end{array}$ & 1 & 10 & 886 & 12 & 0.01 \\
\hline $\begin{array}{l}\text { Chocolate-tip } \\
\text { Clostera curtula (Linnaeus, 1758) }\end{array}$ & 1 & 10 & 699 & 7 & 0.01 \\
\hline
\end{tabular}


Table 2. Catching data of caught species (continuation)

\begin{tabular}{|c|c|c|c|c|c|}
\hline \multirow[b]{2}{*}{ Families and species } & \multicolumn{5}{|c|}{ Number of } \\
\hline & $\begin{array}{l}\text { Light- } \\
\text { traps }\end{array}$ & Years & $\Sigma 0$ & $\Sigma$ ㅇ & $\begin{array}{l}x^{2} \\
P<\end{array}$ \\
\hline \multicolumn{6}{|l|}{ Lymantriidae } \\
\hline $\begin{array}{l}\text { Pale Tussock } \\
\text { Calliteara pudibunda (Linnaeus, 1758) }\end{array}$ & 4 & 7 & 1,411 & 72 & 0.01 \\
\hline $\begin{array}{l}\text { Yellow-tail } \\
\text { Euproctis similis (Fuessly, 1775) }\end{array}$ & 2 & 9 & 540 & 38 & 0.01 \\
\hline $\begin{array}{l}\text { White Satin Moth } \\
\text { Leucoma salicis (Linnaeus, 1758) }\end{array}$ & 1 & 5 & 157 & 18 & 0.01 \\
\hline \multicolumn{6}{|l|}{ Arctiidae } \\
\hline $\begin{array}{l}\text { Dotted Footman } \\
\text { Pelosia muscerda (Hufnagel, 1766) }\end{array}$ & 3 & 10 & 1,791 & 1,762 & NS \\
\hline $\begin{array}{l}\text { Scarce Footman } \\
\text { Eilema complana (Linnaeus, 1758) }\end{array}$ & 6 & 10 & 8,244 & 6,156 & 0.01 \\
\hline $\begin{array}{l}\text { Common Footman } \\
\text { Eilema lurideola (Zincken, 1817) }\end{array}$ & 5 & 9 & 15,980 & 12,252 & 0.01 \\
\hline \multicolumn{6}{|l|}{ Noctuidae } \\
\hline $\begin{array}{l}\text { Small Quaker } \\
\text { Orthosia cruda (Denis et Schiffermüller 1775) }\end{array}$ & 5 & 7 & 6,820 & 3,201 & 0.01 \\
\hline $\begin{array}{l}\text { Hebrew Character } \\
\text { Orthosia gothica (Linnaeus, 1758) }\end{array}$ & 8 & 9 & 4,565 & 727 & 0.01 \\
\hline $\begin{array}{l}\text { The Satellite } \\
\text { Eupsilia transversa (Hufnagel, 1766) }\end{array}$ & 7 & 10 & 2,974 & 2,911 & NS \\
\hline $\begin{array}{l}\text { The Chestnut } \\
\text { Conistra vaccinii (Linnaeus, 1761) }\end{array}$ & 11 & 10 & 11,479 & 5,428 & 0.01 \\
\hline $\begin{array}{l}\text { Pale-lemon Sallow } \\
\text { Xanthia ocellaris (Borkhausen, 1792) }\end{array}$ & 3 & 8 & 542 & 886 & 0.01 \\
\hline $\begin{array}{l}\text { The Dun-bar } \\
\text { Cosmia trapezina (Linnaeus, 1758) }\end{array}$ & 6 & 8 & 2,097 & 1,483 & 0.01 \\
\hline $\begin{array}{l}\text { Lesser Belle } \\
\text { Colobochyla salicalis (Denis et Schiffermüller, 1775) }\end{array}$ & 2 & 9 & 2,056 & 614 & 0.01 \\
\hline $\begin{array}{l}\text { Jubilee Fan-foot } \\
\text { Zanclognatha lunalis (Scopoli, 1763) }\end{array}$ & 4 & 10 & 12,077 & 8,234 & 0.01 \\
\hline
\end{tabular}

The flying period and primary food plants of caught moths are shown in Table 3.

\section{METHODS}

All species were processed separately, but by the same method. The number of captured males and females was counted for the entire swarming. These were summarized and the difference in level of significance was calculated with $\chi^{2}$ test.

For each swarming we calculated the percentage of males and females. We also calculated the values of the coefficients of variation, which express the deviations in average percentages. 
Table 3. The flying period and primary food plants of caught moths

\begin{tabular}{|c|c|c|}
\hline Families and species & Flying period of moths & Primary food plants \\
\hline \multicolumn{3}{|l|}{ Lasiocampidae } \\
\hline P. populi L. & October-November & Quercus, Betula, Populus, Tilia \\
\hline E. rimicola Den. et Schiff. & September-October & Quercus \\
\hline W. cultraria Fabr. & May-June; July-August & Fagus \\
\hline S. harpagula Esp. & May-June; July-August & Tilia, Betula, Quercus \\
\hline \multicolumn{3}{|l|}{ Thyatiridae } \\
\hline T. or Den. et Schiff. & April-May; August & Populus \\
\hline \multicolumn{3}{|l|}{ Geometridae } \\
\hline C. punctaria $\mathrm{L}$. & April-May; July-August & Quercus, Betula \\
\hline C. linearia Hbn. & May-June; July-August & Fagus, Quercus, Betukla \\
\hline E. dilutata Den. et Schiff. & September-November & Quercus, Acer, Betula, Ulmus \\
\hline E. nebulata Scop. & June-August & Alnus Quercus, Acer, Betula \\
\hline M. alternata Den. et Schiff. & April-May; July-August & Salix, Alnus, Prunus \\
\hline C. pennaria $\mathrm{L}$. & September-November & Carpinus, Quercus, Tilia, Salix \\
\hline B. betularia $\mathrm{L}$. & May-June; July-August & Betula, Ulmus, Salix, Fraxinus \\
\hline H. punctinalis Scop. & May-July & Quercus, Betula \\
\hline E. bistortata Gze. & April-May & Polyphagous (Acer, Alnus) \\
\hline \multicolumn{3}{|l|}{ Notodontidae } \\
\hline Ph. bucephala L. & May-June ; July-August & Quercus, Tilia, Salix \\
\hline P. plumigera Den. et Schiff. & October-December & Acer, Fagus, Prunus \\
\hline C. pigra $\mathrm{Hfn}$. & April-June; July-August & Salix \\
\hline C. curtula $\mathrm{L}$. & April-May; June-August & Populus, Salix \\
\hline \multicolumn{3}{|l|}{ Lymantriidae } \\
\hline C. pudibunda L. & May-June & Fagus, Carpinus, Ulmus, Tilia, \\
\hline E. similis Fuesl. & June-July & Qurcus-, Ulmus-, Tilia, Salix \\
\hline L. salicis L. & June-July & Populus \\
\hline \multicolumn{3}{|l|}{ Arctiidae } \\
\hline P. muscerda Hfn. & July-August & Lichenes \\
\hline E.complana L. & July-August & Lichenes \\
\hline E. lurideola Znck. & July-August & Lichenes \\
\hline \multicolumn{3}{|l|}{ Noctuidae } \\
\hline O. cruda Den. et Schiff. & March-April & Quercus, Betula, Acer, Carpinus \\
\hline O. gothica $\mathrm{L}$. & March-April & Quercus, Tilia, Ulmus, Betula \\
\hline E. transversa $\mathrm{Hfn}$. & September-April & Quercus, Betula \\
\hline C. vaccinii $\mathrm{L}$. & September-April & Quercus, Betula \\
\hline X. ocellaris Brkh. & September-April & Quercus, Tilia, Acer, Ulmus, \\
\hline C. trapezina $\mathrm{L}$. & June-September & Quercus, Fagus, Betula, Acer \\
\hline C. salicalis Den. et Schiff. & May-August & Populus, Salix \\
\hline Z. lunalis Scop. & May-September & Fagus \\
\hline
\end{tabular}




\section{RESULTS AND DISCUSSION}

The results are shown in Table 4.

Table 4. The percentage of males and females, deviations and coefficients of variation.

\begin{tabular}{|c|c|c|c|c|c|c|c|}
\hline Families and species & Moths & $\begin{array}{c}\text { Mean } \\
0 \%\end{array}$ & ots & ơ CV & $\begin{array}{c}\text { Mean } \\
\$ \%\end{array}$ & +s & + $\mathrm{CV}$ \\
\hline \multicolumn{8}{|l|}{ Lasiocampidae } \\
\hline Poecilocampa populi $\mathrm{L}$. & 2,134 & 0.83 & 0.177 & 0.21 & 0.17 & 0.177 & 1.04 \\
\hline Eriogaster rimicola Den. et Schiff. & 2,067 & 0.98 & 0.018 & 0.02 & 0.02 & 0.018 & 0.90 \\
\hline \multicolumn{8}{|l|}{ Drepanidae } \\
\hline Watsonalla cultraria Fabr. & 2,308 & 0.37 & 0.111 & 0.30 & 0.63 & 0.106 & 0.17 \\
\hline Sabra harpagula Esp. & 1,022 & 0.88 & 0.042 & 0.05 & 0.12 & 0.042 & 0.37 \\
\hline \multicolumn{8}{|l|}{ Thyatiridae } \\
\hline Tethea or Den. et Schiff. & 3,292 & 0.75 & 0.092 & 0.12 & 0.25 & 0.106 & 0.42 \\
\hline \multicolumn{8}{|l|}{ Geometridae } \\
\hline Cyclophora punctaria L. & 2,528 & 0.61 & 0.179 & 0.29 & 0.39 & 0.179 & 0.46 \\
\hline Cyclophora linearia $\mathrm{Hbn}$. & 8,862 & 0.48 & 0.102 & 0.21 & 0.52 & 0.092 & 0.18 \\
\hline Epirrita dilutata Den. et Schiff. & 1,340 & 0.89 & 0.040 & 0.04 & 0.11 & 0.034 & 0.31 \\
\hline Euchoeca nebulata Scop. & 3,083 & 0.86 & 0.141 & 0.16 & 0.12 & 0.141 & 1.17 \\
\hline Macaria alternata Den. et Schiff. & 5,004 & 0.75 & 0.114 & 0.15 & 0.25 & 0.115 & 0.46 \\
\hline Colotois pennaria $\mathrm{L}$ & 5,128 & 0.91 & 0.086 & 0.09 & 0.09 & 0.086 & 0.96 \\
\hline Biston betularia $\mathrm{L}$. & 4,393 & 0.99 & 0.011 & 0.01 & 0.01 & 0.011 & 1.10 \\
\hline Hypomecis punctinalis Scop. & 15,553 & 0.88 & 0.076 & 0.09 & 0.12 & 0.076 & 0.63 \\
\hline Ectropis bistortata Goeze & 19,443 & 0.97 & 0.048 & 0.05 & 0.03 & 0.045 & 1.50 \\
\hline \multicolumn{8}{|l|}{ Notodontidae } \\
\hline Phalera bucephala $\mathrm{L}$. & 502 & 0.98 & 0.019 & 0.02 & 0.02 & 0.019 & 0.95 \\
\hline Ptilophora plumigera Den. et Schiff. & 2,393 & 0.90 & 0.054 & 0.06 & 0.10 & 0.054 & 0.54 \\
\hline Clostera pigra $\mathrm{Hfn}$ & 886 & 0.99 & 0.013 & 0.01 & 0.01 & 0.008 & 0.80 \\
\hline Clostera curtula $\mathrm{L}$. & 699 & 0.99 & 0.009 & 0.01 & 0.01 & 0.009 & 0.90 \\
\hline \multicolumn{8}{|l|}{ Lymantriidae } \\
\hline Calliteara pudibunda $\mathrm{L}$. & 1,183 & 0.95 & 0.039 & 0.04 & 0.05 & 0.039 & 0.78 \\
\hline Euproctis similis Fuesl. & 578 & 0.94 & 0.037 & 0.04 & 0.06 & 0.036 & 0.60 \\
\hline Leucoma salicis $\mathrm{L}$. & 175 & 0.89 & 0.073 & 0.08 & 0.11 & 0.074 & 0.67 \\
\hline \multicolumn{8}{|l|}{ Arctiidae } \\
\hline Pelosia muscerda Hfn. & 3,553 & 0.53 & 0.108 & 0.20 & 0.47 & 0.108 & 0.23 \\
\hline Eilema complana $\mathrm{L}$. & 13,400 & 0.56 & 0.129 & 0.23 & 0.44 & 0.129 & 0.29 \\
\hline Eilema lurideola Zinck. & 28,232 & 0.68 & 0.174 & 0.26 & 0.32 & 0.174 & 0.54 \\
\hline \multicolumn{8}{|l|}{ Noctuidae } \\
\hline Orthosia cruda Den. et Schiff. & 10,021 & 0.66 & 0.105 & 0.16 & 0.34 & 0.105 & 0.31 \\
\hline Orthosia gothica L. & 5,292 & 0.88 & 0.071 & 0.08 & 0.12 & 0.071 & 0.59 \\
\hline Eupsilia transversa $\mathrm{Hfn}$. & 5,885 & 0.51 & 0.083 & 0.16 & 0.49 & 0.083 & 0.17 \\
\hline Conistra vaccinii $\mathrm{L}$ & 16,907 & 0.69 & 0.123 & 0.18 & 0.31 & 0.123 & 0.40 \\
\hline Xanthia ocellaris Borkh. & 1,428 & 0.39 & 0.194 & 0.50 & 0.61 & 0.194 & 0.32 \\
\hline Cosmia trapezina $\mathrm{L}$. & 3,580 & 0.58 & 0.082 & 0.14 & 0.42 & 0.082 & 0.19 \\
\hline Colobochyla salicalis Denis et Schiff. & 2,670 & 0.81 & 0.085 & 0.10 & 0.19 & 0.085 & 0.45 \\
\hline Zanclognatha lunalis Scop. & 20,311 & 0.62 & 0.130 & 0.21 & 0.38 & 0.130 & 0.34 \\
\hline
\end{tabular}

Notes: Mean $\sigma^{\circ} \%$ and Mean $\% \%=$ averaged percentage of males and females, $\sigma^{\star} \mathrm{s}$ and $\% \mathrm{~s}=$ deviations, $\quad \mathrm{\sigma}^{\top} \mathrm{CV}$ and $+\mathrm{CV}=$ coefficient of variations. 
We found the majority of moths collected in light traps are males. This result is true of 29 species from the investigated 32 species. However, the proportion of males and females of each species, and even within the same species, differed greatly during each swarming.

One probable explanation may be the protandry for greater number of males. Cordillot (1989) established that occurrence of the male of the European corn-borer (Ostrinia numilalis Hbn.) in the light trap preceded the females' occurrence by $3.8 \pm 1.5$ days on average. This phenomenon was named "protandry" by Stockel and Peyelut (1984). That the females of some species are attracted to light in greater number after mating may be the cause of this.

Yathom (1981) found the most frequently light trapped Egyptian bollworm (Earias insulana Boisduval) females mated once. Lopez et al. (2000) found that the overwhelming majority of the females of Mythimna unipuncta (Haworth) flew to light after egg-laying. We also observed the "protandry" phenomenon in the case of the dotted footman Pelosia muscerda Hfn. in Tompa 1970; the male and female ratio is equal with this species. Males and females of both species (Pelosia muscerda Hfn. and Eupsilia transverse Hfn.), are captured nearly in similar number. Cordillot (1989) found that the overall ratio of European corn-borer (Ostrinia nubilalis $\mathrm{Hbn}$.) was found almost the same; of the captured moths, $52.7 \%$ were males and $47.3 \%$ were females.

Watsoniana cultraria Fabr. is the only one species captured by light traps that showed a significant female majority. We examined 8 swarmings; females outnumbered males in 7 of them. The males of this moth also fly in the sunlight and they can usually be seen among the higher branches of beech trees. This may be a reason why fewer males of this species are captured at night.

For decades it has been known that the proportion of male and female individuals of various insect species caught by light trap tends to differ. This fact proves that the ratio of the various species represented the catch are not the same as the ratio that appears in nature (Kiss et al. 2003). The reasons for this fact may be many. Flight is difficult for females because of their increased weight due to developing eggs. The males may be more active as they visit the females with the aim of the mating. It is also possible that the males have a greater affinity to light (Waringer 2003).

Acknowledgement: We thank Dr. Pál Szontagh who gave the light trap data of Forest Research Institute to Dr. Sándor Szabó and Dr. László Nowinszky in the 1970s. These data were used in our study.

\section{REFERENCES}

Altermatt, F. BAumeyer, A. Ebert, D. (2009): Experimental evidence for male biased flightto-light behavior in two moth species. Entomologia Experimentalis et Applicata 130: 259-265.

BÜRGÉS, GY. GÁL, T. (1980): Biology of chestnut pests, damage forecasting and drawing up pest control conditions. PhD Dissertation. 184 p.

ChARLton, R. E. - CARDE R. T. - WALlnER W. E. (1999): Synchronous Crepuscular Flight of Female Asian Gypsy Moths: Relationships of Light Intensity and Ambient and Body Temperatures Journal of Insect Behavior 12 (4): 517-537.

Charlton R. E. - CARDE R. T. - WALlner W. E. (1999): Synchronous Crepuscular Flight of Female Asian Gypsy Moths: Relationships of Light Intensity and Ambient and Body Temperatures Journal of Insect Behavior 12 (4): 517-537.

CoRDILlOT, F. P. (1989): Dispersal, flight and oviposition strategies of the European corn borer, Ostrinia nubilalis Hbn. (Lepidoptera: Pyralidae). PhD Dissertation. Basel. 134 p. 
CORDILlOT, F. P. DUElli, P. (1986): Eine richtungsspezifische Lichtfangmethode zur Erfassung von Populationsbewegungen nachts fliegender Insekten. Mitt. der Schweiz. Ent. Ges., 59: 275-281.

CZENCZ, K. (1973): Autökológiai vizssgálatok a káposztamollyal (Plutella maculipennis Curt. Lep.: Plutellidae) kapcsolatban Magyarországon [Autecological investigations on the diamondback-moth (Plutella maculipennis Curt., Lep.: Plutellidae) in Hungary]. Növényvédelem. 9 (6): 242-246. (in Hungarian)

DiCKLER, E. STEUERWALD, F. (1997): Untersuchungen zur Populationsdynamik von FruhjahrsNoctuiden in Apfelanlagen mit Hilfe von automatischen Lichtfallen. Mitteilungen der Deutschen Gesellschaft für Allgemeine und Angewandte Entomologie. 11 (1-6): 251-254. Abstract.

El-Abdullah, F. MochidA, O. ARIDA, G. BASIliO, R. P. (1984): Monitoring the adult densities of the striped rice borer, Chilo suppressalis Walker, and laboratory evaluation of certain insecticides against it's larvae in the Philippines. J. Agric. Res. Tanta Univ. 10 (3): 1055-1062.

EL-DEEB, M. A. (1992): Sex ratio, mating ability and oogenesis for three species of corn borer moths caught in light traps at Sharkia Region. Annals of Agricultural Sciense, Moshtohor. 30 (1): 555-564.

ElliotT, W. M. DIRKS, V. A. (1979): Postmating age estimates for female European corn borer moths, (Ostrinia nubilalis /Lepidoptera: Pyralidae/, using timerelated changes in spermatophores. Can. Ent., Ottawa. 111 (12): 1325-1335.

GARRIS, H. W. SNYDER, J. A. (2010): Sex-specific attraction of moth species to ultraviolet light traps. Southeastern Naturalist 9 (3): 427-434. DOI: 10.1656/058.009.0302

ITÄMIES J. KYRK J. PULLIAINEN, E. (1986): Flight pattern of Entephria caesiata (Lepidoptera: Geometridae) in E. Finnish Forest Lappland. Ann. Zool. Fennici, 23: 151-156.

JÁRFÁs, J. SZABÓ, E. SOHAJDA, I. (1974): A vetési bagolylepke (Scotia segetum Den. et Schiff.) repülésének vizsgálata speciális fénycsapdarendszerekkel 1965-71 években [Investigation on the fly of turnip moth (Scotia segetum Den. et Schiff.) using a special system of light-traps in years 19651971] Növényvédelem. 10 (3): 104-109. (in Hungarian)

JERMY, T. (1961): Kártev rovarok rajzásának vizsgálata fénycsapdával. [Investigation of the swarming of harmful insects using light-traps] A Növényvédelem Id szer Kérdései. 2: 53-61. (in Hungarian)

Kiss, M. NOWINSZKY, L. PUSKÁs, J. (2003): The ratio of males and females in the catch. In: NOwINSZKY, L. (ED.) The Handbook of Light Trapping. Savaria University Press, Szombathely, Hungary. 189-194.

LESZNYÁK, M. SZARUKÁN, I. MÉSZÁROS, Z. (1993): A kukoricamoly (Ostrinia nubilalis Hübner) szexuálindexének alakulása a populációnagyság és a meteorológiai tényez $\mathrm{k}$ függvényében, fénycsapda fogási eredmények alapján. [Sexual index of the European corn borer (Ostrinia nubilalis Hübner) as a function of population size and meteorological factors, based on light-trap catches] Növényvédelem. 29 (7): 307-316. (in Hungarian)

LOPEZ, C. SANS, A. EIZAGuirRe, M. (2000): Vuelos de la defoliadora de maíz, pastos y céspedes, Mythimna (Pseudaletia) unipuncta (Haworth) en la zona de Lleida. [Flights of the armyworm moth, Mythimna (Pseudaletia) unipuncta (Haworth), in the area of Lleida, Spain]. Boletin de Sanidad Vegetal, Plagas. 26 (2): 255-259. Abstract. (in Spain)

MALICKY, H. (1974): Über das Geschlechterverhältnis von Lepidopteren in Lichtfallen. Zeit. Ang. Ent. 75: 113-129.

MALLET, J. (1984): Sex roles in the Ghost Moth Hepialus humuli (L) and a review of mating in the Hepialidae (Lepidoptera). Zoological Journal of the Linnean Society, 79: 67-82.

MOHAINÉ, K. HERCZIG, B. (1979): Néhány kártev bagolylepke (Lepidoptera: Noctuidae) ivararánya fénycsapdákban. [The sex ratio of some noctuid moths in light-traps (Lepidoptera: Noctuidae)]. Növényvédelem. 15 (5): 193-197. (in Hungarian)

MYers, J. H. - BoetTneR, G. - ElKinTON, J. (1998): Material effects in Gypsy Moth: Only sex ratio varies with population density. Ecology, 79 (1): 305-314.

NANU, N. KÖNIG, F. (1968): Light-capcane aplică prinderea de forestiere molii dăunătoare [Lighttraps apply to catching of forestry harmful moths]. Revista Pádurilor. 83 (8): 430-434. (in Rumanian)

NovÁK, I. (1974): Sexualindex bei Lepidopteren in dem Lichtfallen. Fol. Ent. Hung. 27. Suppl. 143-152.

NOWINSZKY, L. (2003): The Handbook of Light Trapping. Savaria University Press, Szombathely, Hungary. $276 \mathrm{p}$. 
NOWINSZKY, L. KISS, M. (1981): Az ivararány módosulásának szerepe a vetési bagolylepke (Scotia segetum Schiff.) gradációinak kialakulásában. [The role of changes of the sex ratio in the outbreaks of turnip moth (Scotia segetum Schiff.)]. Növényvédelem. 17 (10-11): 156-158. (in Hungarian)

REINEKE A. - ZeBITZ, C. P. W (1998): Flight ability of gypsy moth females (Lymantria dispar L.) (Lep., Lymantriidae): a behavioural feature characterizing moths from Asia? Journal of Applied Entomology 122 (1-5): 307-310.

SADEK, M. M. (2001): Polyandry in field-collected Spodoptera littoralis moths and laboratory assessment of the effects of mating history. Entomologia Experimentalis et Applicata. 98 (2): 165-172. Abstract.

SATHIYANANDAM, V. K. R. BASKARAN, R. K. M. (1999): Response of groundnut leafminer, Aproaerema modicella Deventer, to mercury light trap and visible light spectra. Journal of Entomological Research. 23 (3): 209-215. Abstract.

SCHURR, E. (1971): Erfahrungen bei Flugkontrollen von Clysia ambiguella Hbn. Mit Lichtfallen-enfang im südbadischen Raum. Wein Wiss., Wiesbaden 26 (7-8): 225-241.

Showers, W. B. ReED, G. L. OlOuMISADEGHI, H. (1974): Mating studies of female European Corn Borers: relationship between depositio of eggmasses on corn and captures in light traps. J. Econ. Ent. Baltimore. 67 (5): 616-619.

SKUHRAVÝ, V. SKUHRAVÁ, M. BREWER, W. (1993): The saddle gall midge Haplodiposis marginata (Diptera: Cecidomyidae) in Czech Republic and Slovak Republic from 1971-1989. Acta Soc. Zool. Bohem. 57: 117-137.

STOCKEL, J. PEYELUT, L. (1984): Importance of protandry in effectiveness of using pheromone traps to estimate numerical importance of males of the European corn borer (Ostrinia nubilalis $\mathrm{Hbn}$.) (Lepidoptera: Pyralidae). Acta oecol. Appl., 5 (3): 235-243.

Story, J. M. GoOD, W. R. White, L. J. (2001): Response of the knapweed biocontrol agent Agapeta zoegana L. (Lepidoptera: Cochylidae) to portable lights. Pan-Pacific Entomologist. 77. (3): 219-225. Abstract.

SZARUKÁN, I. (1975): Data to the biology of the noctuid Mamestra suasa Schiff (in Hungarian). Növényvédelem. 11 (7): 289-297.

SZE KE, K. SZARUKÁN, I. (1982): Az ivararány és a populáció dinamikájának összefüggése a tarka kertibagolylepke (Mamestra suasa Den. et Schiff.) példáján. [Connections between the sex ratio and population dynamics on the example of Mamestra suasa Den. et Schiff]. Növényvédelem. 18 (10): 433-436, (in Hungarian)

TABAdKAni, S. M. Ashouri, A. RAhimi-Alangi, V. FAthi-MoghaddaM, M. (2013): When to estimate sex ratio in natural populations of insects? A study on sex ratio variations of gall midges within a generation, 16 (1): 54-59. DOI: 10.1111/j.1479-8298.2012.00537.x

TersKov, J. A. KolOMIEC, N. G. (1966): Szvetovïje lovuski i ih iszpol'zovanijev zascsita rasztenij. [Affection of Dendrolimus sibiricus Tschetv. (Lepidoptera, Lasiocampidae) for ultraviolet light]. Entomol. Obozrenniye. 61 (2): 306-309 (in Russian)

Wallner, W. E. - Humble, L. M. - Levin, R. E. - Baranchikov, Y. N. - Cardé, R. T. (1995): Response of adult Lymantriid moths to illumination devices in the Russian Far East. J. Econ. Entomol., 88 (2): 337-342.

WARD, J. B. Henderson, I. M. PATrick, B. H. Norrie, P. H. (1996): Seasonality, sex ratios and arrival pattern of some New Zealand caddis (Trichoptera) to light-traps Aquatic Insects. 18. (3): 157-174. Abstract.

WARINGER J. A. (2003): Light-trapping of caddisflies at the Thaya Lower Austria, a river influenced by pulsating hypolimnetic water release. International Review of Hydrobioogy, 88: 139-153.

WILLIAMS, C. B. (1939): An analysis of four years captures of insects in a light-trap. Part I. General survey: sex flight. Trans. Roy. Ent. Soc. London. 89: 79-132.

YATHOM S. (1981): Sex ratio and mating status of Earias insulana females (Lepidoptera: Noctuidae) collected from light traps in Israel. Israel Journal of Entomology, 15: 97-100. 